\title{
First footprints occurrence from the Muschelkalk detritical unit of the Catalan Basin: 3D analyses and palaeoichnological implications
}

\author{
Eudald MUJAL ${ }^{1 *}$, Josep FORTUNY², Pablo RODRÍGUEZ-SALGADO ${ }^{1}$, Marc DIVIU ${ }^{1}$, \\ Oriol OMS ${ }^{1} \&$ Àngel GALOBART $T^{2}$
}

\begin{abstract}
${ }^{1}$ Universitat Autònoma de Barcelona. Departament de Geologia. 08193 Bellaterra, Spain; eudald.mujal@uab.cat; pablorodriguezsalgado@gmail.com; mdiviu@gmail.com; joseporiol.oms@uab.cat

${ }^{2}$ Institut Català de Paleontologia Miquel Crusafont. Mòdul ICP - Facultat de Biociències. Universitat Autònoma de Barcelona. 08193 Bellaterra, Spain; josep.fortuny@icp.cat; angel.galobart@icp.cat

* Corresponding author
\end{abstract}

Mujal, E., Fortuny, J., Rodríguez-Salgado, P., Diviu, M., Oms, O. \& Galobart, À. 2015. First footprints occurrence from the Muschelkalk detrital unit of the Catalan Basin: 3D analyses and palaeoichnological implications. [Primer registro de huellas en la unidad detrítica del Muschelkalk de la Cuenca Catalana: Análisis 3D e implicaciones paleoicnológicas]. Spanish Journal of Palaeontology, 30 (1), 97-108.

\begin{abstract}
Fossil vertebrate footprints are known from several Triassic localities of the Iberian Peninsula. Geological setting and palaeoichnological analyses are presented from the first recovered tetrapod footprints from the Middle Muschelkalk facies of the Iberian Peninsula. The studied outcrop is 40 km NW from Barcelona, in the Catalan Coastal Ranges (Catalan Basin, NE Iberian Peninsula). The stratigraphic section is ascribed to Middle Muschelkalk facies from Late Anisian-Early Ladinian age (Middle Triassic), and comprises mainly red mudstones with interbedded sandstones. Tetrapod footprints are located at the upper part of decimetric mediumgrain size sandstone intercalated in metric-submetric mudstone beds sequence. The general palaeoenvironment is a floodplain with episodic torrential events. Several 3D models from footprints were made by photogrammetry technique, being useful in the morphological description and depth analyses as indicator of the trackmaker's pressureweight distribution and locomotion-substrate interaction.
\end{abstract}

\section{RESUMEN}

En la Península Ibérica se conocen varias localidades de huellas fósiles de vertebrados del Triásico. En este trabajo se presentan el contexto geológico y los análisis paleoicnológicos de las primeras huellas fósiles de tetrápodos encontradas en facies Muschelkalk Medio de la Península Ibérica. El área de estudio está a $40 \mathrm{~km}$ al NW de Barcelona, en las Cordilleras Costero Catalanas (Cuenca Catalana, NE Península Ibérica). La sección estratigráfica pertenece a las facies Muschelkalk Medio de edad Anisiense superior-Ladiniense inferior (Triásico Medio), y está formada principalmente por lutitas rojas con intercalaciones de areniscas. Las huellas de tetrápodo se encuentran en la parte alta de una secuencia de capas de areniscas de grano medio decimétricas intercaladas con capas lutíticas métricas o submétricas. En general, el paleoambiente es una llanura de inundación con eventos torrenciales episódicos. Se generaron mediante fotogrametría diversos modelos 3D de las huellas, que ayudan en la descripción morfológica y análisis de profundidad como indicadores 
Tetrapod footprints are preserved in convex hyporelief in a sandstone bed with ripple laminations, mud-cracks and invertebrate traces. Substrate under the sand was muddy and soft, with progressive desiccation. There are eight footprints from different specimens and trackmakers. Seven of them are attributed to Isochirotherium isp. and Chirotherium isp. In special, three of them clearly resemble the pentadactyl morphology of chirotheriid pes. Potential trackmakers are crurotarsians. The last footprint is isolated and is referable to Rhynchosauroides isp. Potential trackmaker is a lacertoidtype reptile. The finding partially confirms the presence of homogeneous fauna diversity in the Middle Triassic of Europe, dominated by the same ichnofamilies reported here.

Keywords: Middle Triassic, Isochirotherium, Chirotherium, Rhynchosauroides, photogrammetry. de distribución presión-peso del productor e interacción locomoción-sustrato. Las huellas de tetrápodo se preservan en hiporelieve convexo en una capa de arenisca con ripples, grietas de desecación y trazas de invertebrados. El sustrato bajo la arena era fangoso y blando, con progresiva desecación. Hay ocho huellas de diferentes especímenes y productores. Siete de ellas se atribuyen a Isochirotherium isp. y Chirotherium isp. En especial, tres de ellas preservan la típica morfología pentadáctil de los pies de chirotheridos. Los potenciales productores son crurotarsos. La otra huella está aislada y se atribuye a Rhynchosauroides isp. El potencial productor es un reptil tipo lacértido. El hallazgo confirma la presencia de diversidad faunística homogénea en el Triásico Medio de Europa, dominado por las mismas icnofamílias citadas.

Palabras clave: Triásico Medio, Isochirotherium, Chirotherium, Rhynchosauroides, fotogrametría.

\section{INTRODUCTION}

Tetrapod footprints are known from several Iberian Peninsula localities of Buntsandstein and Lower Muschelkalk facies, mainly corresponding to Middle Triassic. These sites are in the Catalan Coastal Ranges (Calzada, 1987; Fortuny et al., 2011 and references therein), Iberian Ranges (Demathieu et al., 1978; García-Bartual et al., 1996; Gand et al., 2010; DíazMartínez \& Pérez-García, 2012), Betic Ranges (PérezLópez, 1993; Demathieu et al., 1999), and Cantabrian Mountains (Demathieu \& Saiz de Omeñaca, 1990). In Serra de Tramuntana (Mallorca, Balearic Islands), tetrapod footprints from Buntsandstein facies were described by Calafat et al. (1987). Nevertheless, in Middle Muschelkalk facies unit (detritical in the Catalan Coastal Ranges) vertebrate fossils have never been reported until now. Here are described the first tetrapod footprints recovered in this facies on Collcardús area from the Catalan Coastal Ranges.

Firstly, these footprints were cited but not described by Fortuny et al. (2012), and no detailed ichnotaxonomic studies were made. Footprints shape is difficult to assess because of the original environmental conditions and the current weathering effects. Fortunately, 3D photogrammetric models are useful for taxonomical implications and are herein made in several footprints. Thus, this is the first ichnological study applying photogrammetry on non-dinosaur Triassic footprints (see also Petti et al., 2009 and Belvedere et al., 2013) and the resulting data enhances the use of this technique on trace fossils.

Fortuny et al. (2011) presented a comprehensive review of the palaeobiogeographic evolution during the Triassic period and remarked the importance of revising the Triassic Iberian fossil localities. The tetrapod footprints reported here enlarge the knowledge of the continental faunas and their geological setting (Middle Muschelkalk facies) gives additional interest in their study as palaeobiogeographic indicators, because in the Catalan Basin the Middle Muschelkalk unit is not carbonated, like in other Triassic localities.

Thus, the main objectives of this work are (1) description and identification applying the photogrammetrical technique and (2) geological contextualization of the tetrapod ichnites.

\section{MATERIAL AND METHODS}

Morphological description of ichnites is based on quantitative and qualitative parameters, following the ones applied by Haubold (1971a, b) and Demathieu (1985), which are: footprint length and width, digits length, digits divarication (angle between digits), cross axis angle (digit III with metapodial-digit line), and manus/pes area ratio. Tetrapod traces are named footprints, ichnites and/or tracks. Digits are numbered from medial (inner) to lateral (outer) side, i.e., I-II-III-IV-V. Biometric measurements are taken with ImageJ v.1.46r (available from http://rsbweb. nih.gov/ij/).

The ichnological analyses are developed by using the photogrammetry technique. It consists in taking photographs in all the perspectives of the object to obtain a 3D model. A comprehensive review of the technique is given in Falkingham (2012). The photographs were taken with a digital camera Sony DSC-H50 9.1 Megapixels and were processed in different open access softwares: 1) VisualSfM v0.5.22 (http://homes.cs.wadhingtin.edu/ ccwu/ $\mathrm{vsfm} /$ ) software matches all the photographs and creates 
the 3D model point cloud; 2) MeshLab v.1.3.2 (http:// meshlab.sourceforge.net/) software is used to create the mesh, scale and orientate the 3D model; 3) With the ParaView v.3.98.1 (http://www.paraview.org) software the $3 \mathrm{D}$ model is coloured to generate the depth map and put the contour lines.

Institutional abbreviations: Slab, in three parts, stored at Institut Català de Paleontologia Miquel Crusafont (ICP) at Sabadell, Catalonia, with the code number IPS-81873a, IPS-81873b, IPS-81873c.

\section{GEOLOGICAL SETTING}

The Triassic of the Catalan Coastal Ranges (CCR) is composed by the classic Germanic facies, which comprises six lithostratigraphic units (Calvet \& Marzo, 1994; Dinarès-Turell et al., 2005): Buntsandstein, Lower, Middle and Upper Muschelkalk, Keuper and Imón formation, and it presents thickness from 500 to $800 \mathrm{~m}$ (Dinarès-Turell et al., 2005). These facies were developed in different rift systems in Central and Eastern Europe and consequently, they cannot be considered as time intervals; therefore there is facies diachronism (López-Gómez et al., 2002).

The studied area is located in the Prelitoral Range of the CCR, in Collcardús range (UTM 31T 411848 X, 4603632 $\mathrm{Y}$ ) from Viladecavalls town, $40 \mathrm{~km} \mathrm{NW}$ from Barcelona
(Figs 1A-B). In this area the Triassic sequence is composed by four of the six main lithostratigraphic units: Buntsandstein, Lower, Middle and Upper Muschelkalk facies. At the base of the Triassic sequence the Buntsandstein facies lies unconformably over the hercynian basement. At the top of the sequence the Tertiary succession lies unconformably over the Upper Muschelkalk. As a result of the Palaeogene compressive phase, in this area the Triassic sequence is inverted and thrusted by the hercynian basement through thin skin tectonics processes (Fig. 1C).

Within the Triassic sequence, the finding is located in the Middle Muschelkalk facies (M2) that in CCR are dated as Late Anisian-Early Ladinian age by palynological methods (Solé de Porta et al., 1987). The Middle Muschelkalk is constituted mainly by red mudstones with interbedded sandstones, which is interpreted as floodplain from fluvial sedimentary palaeoenvironment. The slab bearing tetrapod footprints is located at the upper part of decimetric medium-grain size sandstone intercalated in metric-submetric mudstone beds sequence (Fig. 2). The alternation of medium grained sandstones with mudstones in addition with the primary sedimentary structures, such as planar cross stratification, suggests the ephemeral alluvial currents within a terminal fan model of the Guanta Unit (Calvet \& Marzo, 1994). A combination of lowenergy transport with episodic floods triggered during overflow moments is recorded. These processes generated a floodplain environment, optimal for the ichnite record and preservation.

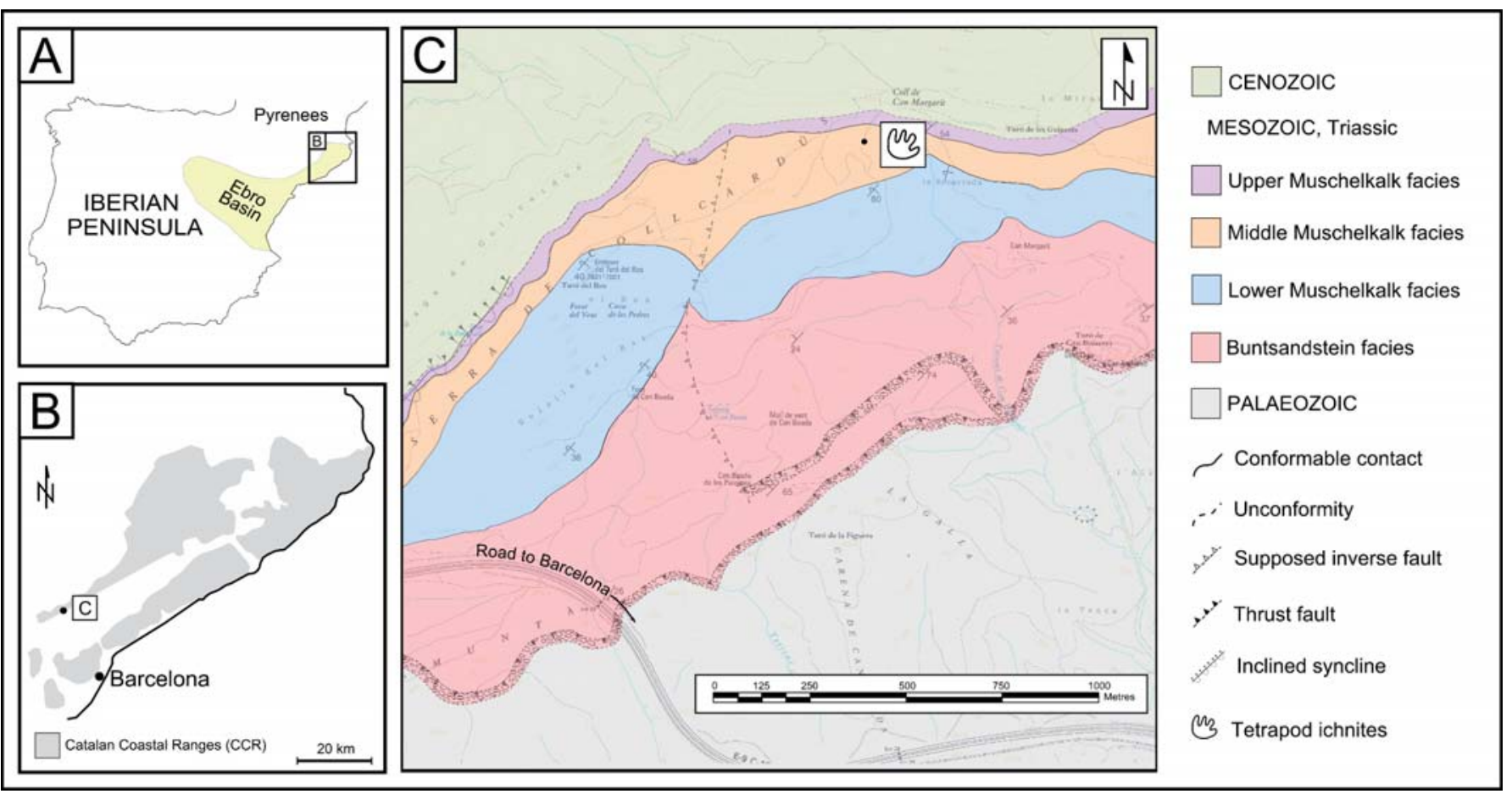

Figure 1. Geological setting. (A) Geographical situation. (B) Regional lithostratigraphy (modified from Durán, 1990). (C) Geological map from the studied area (topographic base modified from Institut Cartogràfic de Catalunya, http://www.icc.cat). 


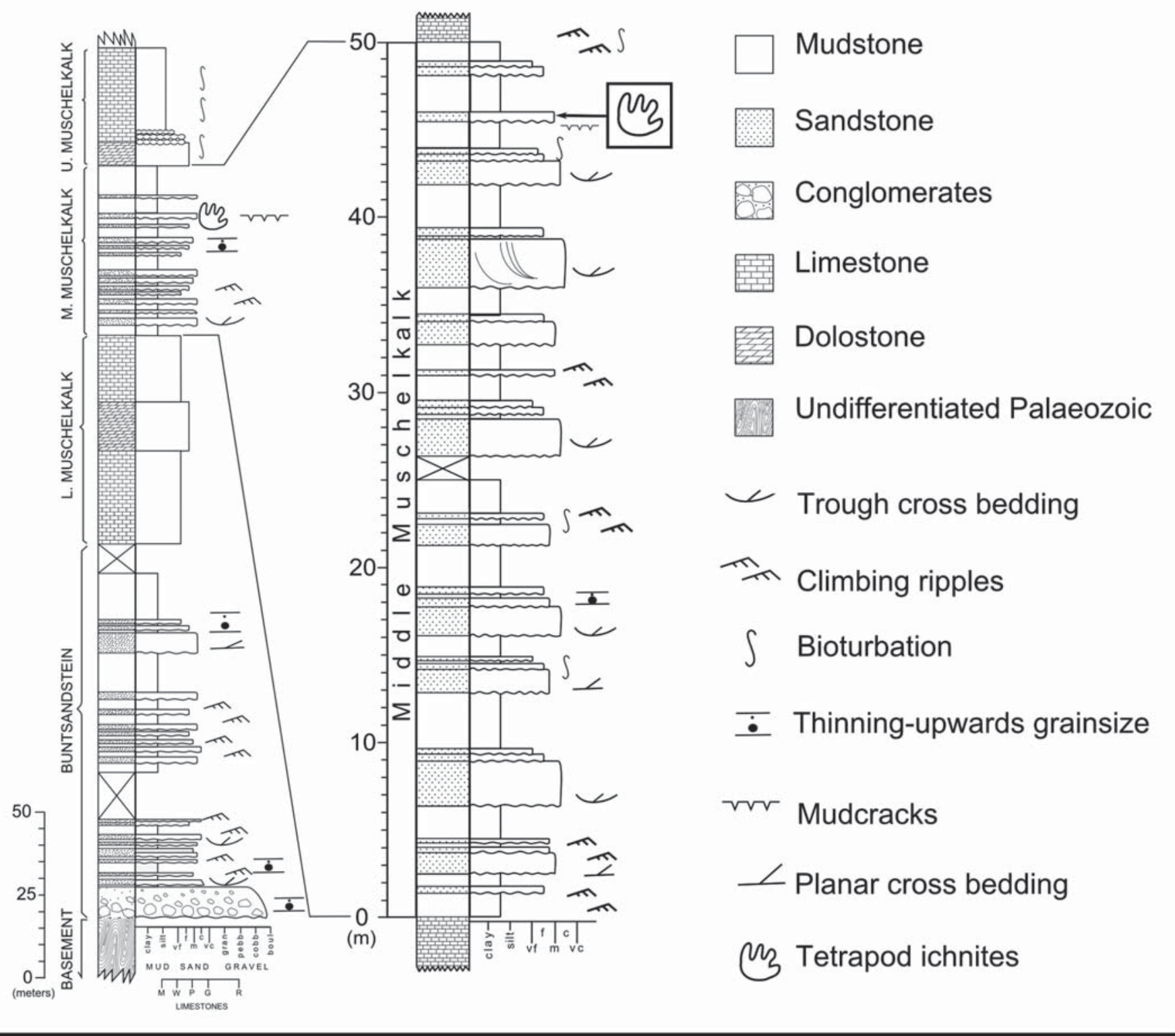

Figure 2. Collcardús Triassic stratigraphical sequence and detailed Middle Muschelkalk section, with ichnites stratigraphical situation.

\section{SYSTEMATIC PALAEOICHNOLOGY}

Ichnites are casts in convex hyporelief preserved in a fine to medium grain size sandstone. There are sedimentary structures corresponding to ripples and soft pebbles (observed in section), and mud-crack structures at the base surface, crossing the footprints. Vertical and sinuous invertebrate traces (burrows) are also present. There are eight tetrapod footprints on the slab base (Fig. 3). Seven ichnites are ascribed to chirotheriid ichnofamily while the other one to the rhynchosauroid ichnofamily.

Morpho-family Chirotheriidae Abel, 1935

Ichnogenus Isochirotherium Haubold, 1971b
Ichnospecies Isochirotherium isp. indet

(Figs 3, 4A-F; Table 1)

Referred specimens. Three pes and one manus footprints (IPS-81873a-c).

\section{Description.}

Pes. Within the three impressions, one of them is complete (I.3 in Figs 4A-C), one preserves digits II-V (Figs 4D-F) and the other one corresponds to the large expulsion rim close to the other chirotheriid ichnogenus footprint (I.4 in Fig. 3). Ichnites correspond to semiplantigrade pentadactyl impressions. They are longer than wider $(174 \times 136 \mathrm{~mm}$ for the complete one). Digits I-IV form a group, in which digit III is the longest, followed by the slightly shorter digit II. 
Table 1. Isochirotherium isp., Chirotherium isp. and Rhynchosauroides isp. ichnites measures (in mm and degrees). Values in asterisk (*) are estimated.

\begin{tabular}{|c|c|c|c|}
\hline \multicolumn{4}{|c|}{ Chirotheriid pes footprints } \\
\hline & $\begin{array}{l}\text { Isochirotherium isp. } \\
\text { (Fig. 4A-C) }\end{array}$ & $\begin{array}{c}\text { Isochirotherium isp. } \\
\text { (Fig. 4D-F) }\end{array}$ & $\begin{array}{l}\text { Chirotherium isp. } \\
\text { (Fig. 4G-I) }\end{array}$ \\
\hline Length & 174.309 & $* 166.064$ & 164.915 \\
\hline Width & 134.490 & - & 152.883 \\
\hline Digit I & 71.446 & - & 48.442 \\
\hline Digit II & 100.604 & 96.228 & 92.103 \\
\hline Digit III & 104.831 & 100.489 & 121.689 \\
\hline Digit IV & 74.223 & 76.438 & 107.905 \\
\hline Digit V & 96.010 & $* 95.569$ & 95.078 \\
\hline $\begin{array}{l}\text { Digits I-IV } \\
\text { length }\end{array}$ & 111.094 & $* 135.306$ & 145.074 \\
\hline $\begin{array}{l}\text { Digits I-IV } \\
\text { width }\end{array}$ & 103.636 & - & 141.184 \\
\hline $\begin{array}{l}\text { Divarication } \\
\text { I-IV }\end{array}$ & 36.441 & - & 52.595 \\
\hline $\begin{array}{l}\text { Cross axis } \\
\text { angle }\end{array}$ & 86.949 & $* 84.781$ & *84.485 \\
\hline $\begin{array}{l}\text { Manus:Pes } \\
\text { (area) }\end{array}$ & - & - & $1: 2.67$ \\
\hline
\end{tabular}

\section{Rhynchosauroides isp. ichnite (Fig. 4J-L)}

\begin{tabular}{ll}
\hline Length & 38.678 \\
Width & - \\
Digit I & - \\
Digit II & $* 12.931$ \\
Digit III & 23.414 \\
Digit IV & 27.538 \\
Digit V & - \\
Divarication & 65.344 \\
II-IV & \\
\hline
\end{tabular}

Digits II and III are closer than digits III and IV. Digits I and IV are similar in length. Digits I-IV divarication is $36.4^{\circ}$. Digits are straight, and pad impressions are wide and slightly convex. Large claw impressions are recognized in digits II, III and IV. The presence of claw impression in digit I remain uncertain due to the preservation. Digit V is rounded and clawless, and it is in a postero-lateral position and slightly outward rotated respect digits I-IV. Digit V pad is nearly as wide as long and is shallower impressed than digits I-IV group and situated at their base. A low ridge separates digit V from the group I-IV. Ichnites present a large expulsion rim, which is higher on the medial (inner, posterolaterally from digit I) part and shallower on the posterior and anterior parts.

Manus. Rounded ichnite, slightly wider than longer $(62 \times 67 \mathrm{~mm})$, with a large expulsion rim, higher in the anterior part. This footprint is probably coupled with the partial pes impression (I.1 with $I .2$ in Fig. 3B).

Discussion. The longer than wider pes, the lengths and proportions of digits I-IV, the claw impressions, the situation and shape of digit $\mathrm{V}$, and cross axis angles are diagnostic traits of Isochirotherium ichnogenus described by Haubold (1971b) and Demathieu (1985), being also the same reported in Demathieu \& Demathieu (2004) and Klein et al. (2011). Otherwise, digit V is longer than I. This character differs from the description of Avanzini \& Cavin (2009), but not from Fuglewicz et al. (1990), who described an Isochirotherium ichnospecies (I. sanctacrucense) with digit $\mathrm{V}$ even longer than digit III. These footprints are also similar to Chirotherium Kaup, 1835 ichnogenus, but it is discarded because digit IV is shorter than digit II, except for larger specimens (Klein \& Haubold, 2003). Digit IV real length has been recognized after the detailed observation of the 3D photogrammetric model, as digit IV appears longer due to impression preservation. Pes footprints also resemble Brachychirotherium Beurlen, 1950, but the presence of large claws (despite bad preserved) and the width of digits I-IV (identified in the 3D model analyses) are characters that differ from this ichnogenus. Moreover, Brachychirotherium occurrences before Late Triassic are doubtful (Klein \& Lucas, 2010; Coram \& Radley, 2013; Hminna et al., 2013). However, Gand et al. (2010) reported Brachychirotherium in Middle Triassic from the Iberian Ranges, thus this assignation may be take with caution. Ichnospecies remains uncertain as no trackway and manus morphologies are preserved.

\section{Ichnogenus Chirotherium Kaup, 1835}

Ichnospecies Chirotherium isp. indet. (Figs 3, 4A-C, G-I; Table 1)

Referred specimens. One pes and two manus footprints (IPS-81873a).

\section{Description.}

Pes. Plantigrade pentadactyl pes impression, attributed to the right side. The footprint is slightly longer than wider $(165 \times 153 \mathrm{~mm})$. Digit III is the longest, followed by 

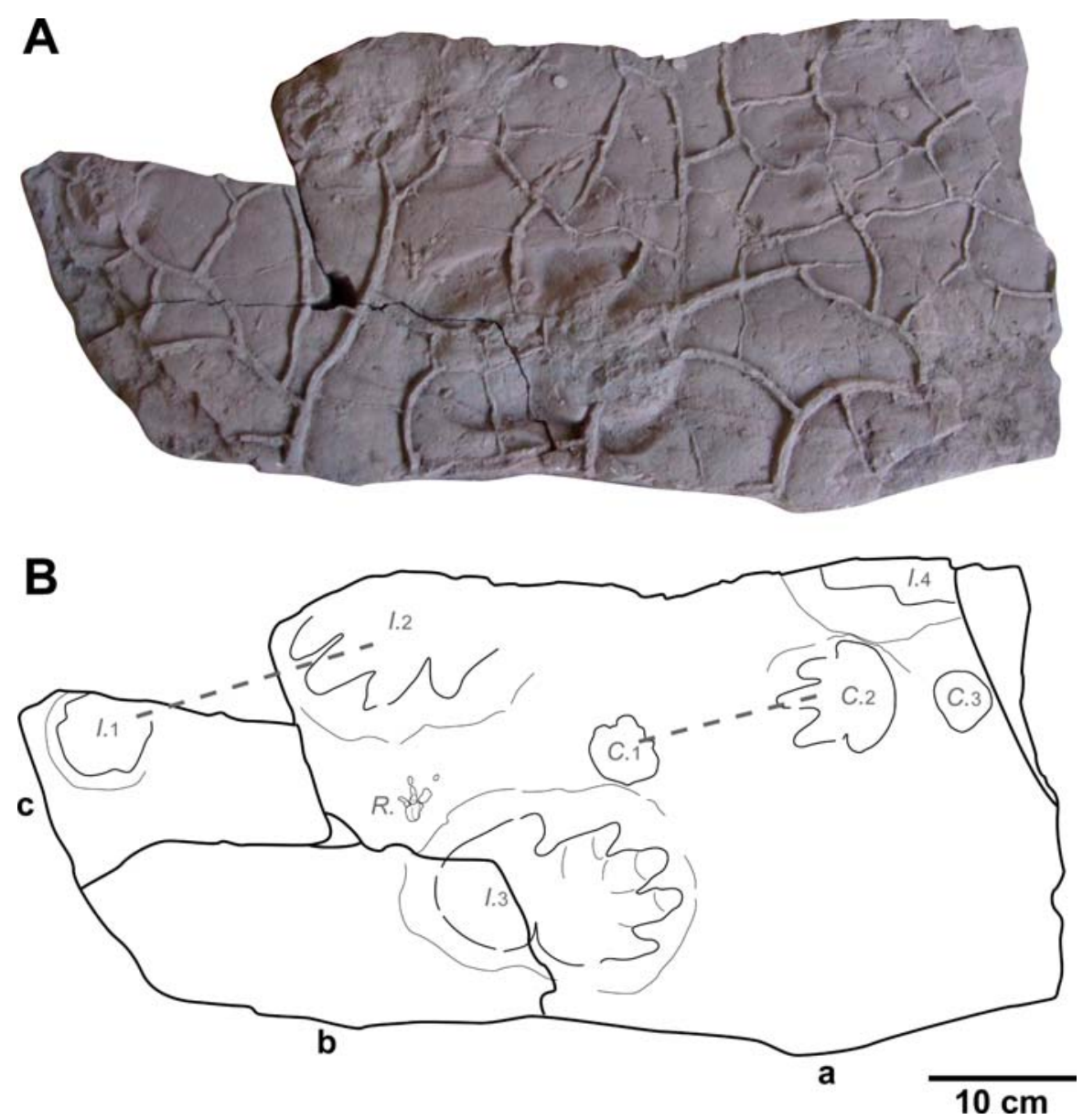

Figure 3. Sandstone slab IPS-81873a, b, c (each letter correspond to each part of the slab) with tetrapod footprints in convex hyporelief (A) and corresponding outline (B). C.: Chirotherium isp. footprints. I.: Isochirotherium isp. footprints. $R$.: Rhynchosauroides isp. footprint. Dashed lines in $C$. and $I$. indicate manus-pes sets. Note the presence of abundant mud cracks. digit IV. They are the deepest impressed digits. Digit II is shorter, and digit I is reduced, also being the shallowest impressed. Digits II to IV are nearly straight, with a slight curvature concave to the lateral (outer) part. Digit II is closer than digit IV to digit III. Digits I-IV divarication is $52.6^{\circ}$. Digit $\mathrm{V}$ is slightly posterior to the group I-IV, but the distal (anterior) part is close to the position of digit I anterior part. Digit V pad is posterior and deeper than digit I pad. There are no claw impressions preserved. Digit IV presents a shallow depression around the anterior part. Although footprint is not deeply impressed and has a smooth shape, an expulsion rim is observed on the medial (inner) part.

Manus. Two shallow rounded impressions (35-42x41$44 \mathrm{~mm}$ ) with no expulsion rim are observed (C.1 and C.3 in Fig. 3B). One of them is beside the Isochirotherium isp. pes footprint (C.1 in Figs 4A-C), this manus is probably coupled with the previously Chirotherium described pes $(C .1$ with C.2 in Fig. 3B; see also manus/pes ratio in Table 1). None of the two ichnites preserve digits morphology.

Discussion. Pes footprint is attributed to Chirotherium as the general pes shape, digits morphology and relative length, digit $\mathrm{V}$ position, cross axis angle and manus/pes area ratio are diagnostic traits from this ichnogenus (e.g., Haubold, 1971a, b; Demathieu, 1985; Klein \& Haubold, 2003; Demathieu \& Demathieu, 2004). The impressions attributed to manus are tentatively assigned to Chirotherium because the association of one of them (C.1 in Figs 4A-C) with the pes ichnite, forming a manus-pes set. A similar specimen to pes footprint is described in Demathieu et al. (1978), which also presents a straight digit V, differing from the generally outward curved shape of the ichnogenus (e.g., Haubold, 1971a, b). Pes footprint presents characters from Brachychirotherium, like digit I-IV divarication and the relative large width. However, digits are much longer than wider, differing from Brachychirotherium (e.g., Haubold, 1971a, b; Demathieu \& Demathieu, 2004). Chirotherium ichnospecies remains also uncertain due to the lack of manus characters and trackways, and also pes impression with more details preserved.

Morpho-family Rhynchosauroidae Haubold, 1966 Ichnogenus Rhynchosauroides Maidwell, 1911

Ichnospecies Rhynchosauroides isp. indet. (Figs 3, 4J-L; Table 1) 
Referred material. One partial ichnite (IPS-81873a).

Description. Small semiplantigrade left footprint of 39 $\mathrm{mm}$ long composed of three digits. Digits are relatively long, thin and inward curved. Digits are in increasing length from II to IV (from left to right; Figs 4J-L). Digit III (23.4 mm length) is the deepest impressed, two elongated and smooth phalangeal pads and a large claw cast are well-recognized. Digit II (12.9 mm length) is a shallow proximal elongated pad impression. Digit IV, the longest, ( $27.5 \mathrm{~mm}$ length) is distinguished by the proximal pad and a shallow claw impression. Digits divarication is $65.3^{\circ}$. Sole is partially impressed, outlined by an expulsion rim.

Discussion. Ichnite length, the slender and inward curved digits and their proportions and morphology are characters of Rhynchosauroides (e.g., Haubold, 1971a, b; Valdiserri \& Avanzini, 2007). Digit impressions are attributed, from the shortest to the longest, to digits II, III and IV, as these are usually the deepest impressed digits in Rhynchosauroides ichnogenus (Demathieu \& Demathieu, 2004). The footprint probably corresponds to a manus impression, because pes are commonly preserved just by the distal parts of the digits or even just by the claw impressions (Haubold, 1971a, b; Valdiserri \& Avanzini, 2007; Diedrich, 2008), and herein described footprint preserves part of the sole. Ichnite distinction is rather difficult due to the presence of mud-cracks and invertebrate traces, the relative rough sediment in comparison with the small ichnite and the proximity of the Isochirotherium isp. pes footprint.

\section{DISCUSSION}

\subsection{Ichnofaunal diversity and preservation}

Three different ichnotaxa are present in the slab (Isochirotherium isp., Chirotherium isp. and Rhynchosauroides isp.), being the chirotheriid trackmakers (crurotarsians) the dominant group over rhynchosauroid trackmakers (lacertoid-type reptile) (sensu Gand et al., 2010). The relative abundance of ichnites and the floodplain within alluvial system palaeoenvironment are indicative of proper conditions for life development and footprints preservation.

Substrate and environmental conditions influence on ichnites shape and preservation causing that footprints usually present extramorphological variations that can difficult the ichnotaxa assignation, overall at ichnospecies level (Klein et al., 2011), as in the herein described footprints. Soft pebbles are observed within the basal part of the cross laminated sandstone, thus the original mudstone substrate surface was partially eroded during sand sedimentation. Mud cracks also influence in footprints preservation, because were formed after trackmakers impressions.

For a more precise ichnotaxonomic assignation, the sequence of structures and processes observed in the slab, in relation to ichnites, should be known, as in this way modifications on tetrapod traces are identified, therefore original footprint shape is recognized. Otherwise, the 3D photogrammetric models are useful in the identification of ichnites shape and sequence of structures formation, because depth maps generated establish the height from each part of the structures. Footprints were impressed at least in two episodes, represented by different ichnotaxa. Processes sequence (including footprints formation) and the inferred substrate conditions variations are as follow:

1) Muddy substrate water saturated. Impression of Rhynchosauroides isp. and Isochirotherium isp. footprints. Expulsion rims are observed in both ichnogenera, being in the chirotheriid footprint larger, in relation to footprint size. Although Isochirotherium isp. complete pes ( $I .3$ in Figs $4 \mathrm{~A}-\mathrm{C}$ ) is close to Rhynchosauroides isp. track (Figs 4J-L), there is no overprinting, and so the order of footprints impression remains uncertain. Preservation of relatively small details in Rhynchosauroides isp. ichnite such as claw impressions and digit pads indicates that substrate was soft and, despite trackmaker small weight and size, footprint is well-distinguished. Despite Isochirotherium isp. footprints are affected by desiccation structures, the resulting shape is not significantly modified. This is likely to the result of sediment compaction and water displacement due to trackmakers weight (trackmakers hardened substrate under pedes pressure). Therefore, displacements due to desiccation process are observed in footprints outer parts, where trackmakers pedes pressure was lower, and also in expulsion rims, which are clearly crossed by mud crack structures. It is clearly documented that footprints are cracked and not the other way round. Footprints are first impressed (substrate humid enough to develop an expulsion rim) and latter cracked (substrate on desiccation process). It is also important to remark that at the footprint centre, mud cracking is hardly noticeable.

2) Substrate desiccation process. Impression of Chirotherium isp. footprints. These footprints were impressed when substrate was decreasing in water content (i.e., it was hardening) and mud crack structures were forming. The smooth shape and the lack of morphological elements (e.g., claw marks and phalangeal pads) indicate that the footprint was impressed in a drying substrate. Despite mud cracks are crossing the footprints, they have no influence on the resulting shape, because there are no displacements in the impressions. 

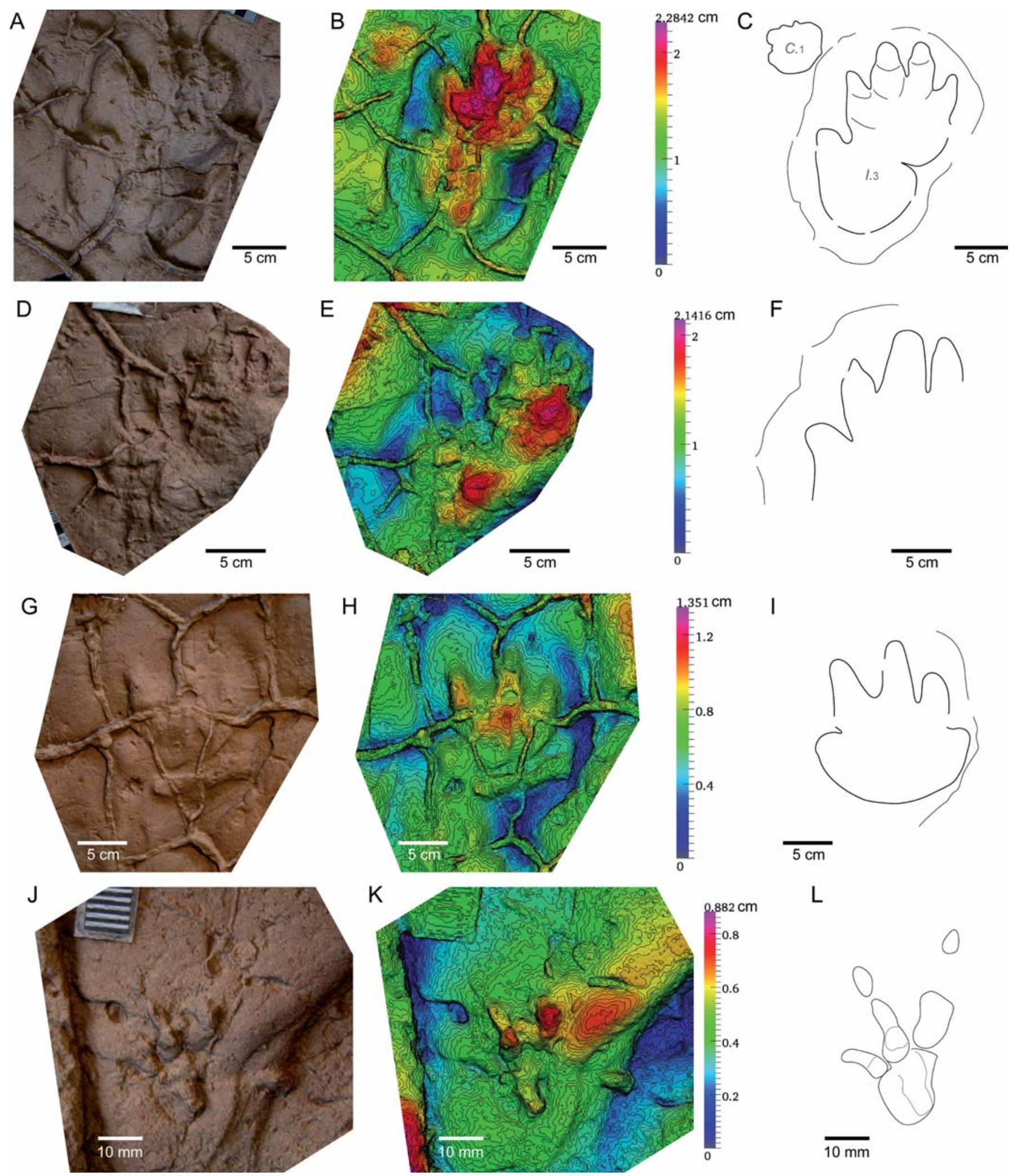

Figure 4. Tetrapod footprints (A, D, G, J) with their corresponding 3D photogrammetric models (B, E, H, K) and outlines (C, F, I, L). Isochirotherium isp. right pes (A-F), Chirotherium isp. right pes (G-I) and Rhynchosauroides isp. left ?manus (J-L). In C, C.1 and I.3 reference Chirotherium and Isochirotherium respectively. 


\subsection{Age and palaeobiogeographic implications}

A previous palynological study dated the Middle Muschelkalk facies from the Catalan Coastal Ranges as Late Anisian-Early Ladinian (Solé de Porta et al., 1987). The stratigraphic range from Chirotherium and Rhynchosauroides is larger (Klein \& Lucas, 2010), so they are not useful in dating, but Isochirotherium isp. age interval is suspected as Anisian-Early Ladinian (Klein \& Lucas, 2010), which is in agreement with the inferred age from palynology.

Marine facies on the Catalan Basin during Late Anisian are represented by the Lower Muschelkalk deposits (Calvet \& Marzo, 1994; López-Gómez et al., 2002; Linol et al., 2009). According to Calvet \& Ramón (1987), these deposits are indicative of a transgression (tidal to shoal bars deposits) followed by a punctual regression (sabkha deposits, Middle Muschelkalk facies) and the posterior transgression continuation. The studied footprints are in the clastic interval within Muschelkalk carbonates that, despite etymological unconsistency, this clastic unit has been referred as Middle Muschelkalk. Marine faunas are known from several Iberian localities from Ladinian age in Upper Muschelkalk facies (see Vía-Boada et al., 1977; Fortuny et al., 2011 for a review). The presence of ichnofauna in the continental deposits may represent palaeobiogeographic indicators: The marine transgression occurred in the Catalan Basin caused that continental fauna migrated while in other Iberian localities (e.g., Iberian Ranges, see Gand et al., 2010) the continental sedimentation persisted. We do not observe ichnotaxa dependence of the environment, i.e., ichnotaxa here reported in clastic sediments are also reported in carbonate settings. Connectivity between clastic and carbonate environments is does strongly suggested.

\section{CONCLUSIONS}

Tetrapod footprints from Middle Muschelkalk facies of the Catalan Basin are reported for the first time in the Iberian Peninsula. Footprints are preserved in convex hyporelief in a sandstone slab from floodplain and fluvial palaeoenvironments.

Three different ichnogenera (Isochirotherium isp., Chirotherium isp. and Rhynchosauroides isp.) have been identified within the eight tetrapod footprints analysed. The 3D models generated with photogrammetry technique permitted precise ichnotaxonomic identification. The application of this technique can be helpful in further analyses on Triassic tetrapod footprints.

During ichnites impression, environment was dry with seasonal humidity, while during the sand sedimentation there was a low to moderate energy aquatic environment.
The age interval provided by the ichnological data is Anisian-Early Ladinian, in agreement with the previous palynological analyses, denoting Late Anisian-Early Ladinian age.

Herein reported tetrapod footprints confirm homogeneous Middle Triassic ichnofauna. Despite facies differences due to transgression within Iberian and Catalan basins, ichnotaxa are similar, thus, connections with neighbouring basins probably persisted.

\section{ACKNOWLEDGMENTS}

Our thanks goes to the organizing committe of the XI EJIP "Encuentro de Jóvenes Investigadores en Paleontología" held in Atarfe (Granada) in 2013, and specially to Carlos Martínez-Perez and Pilar Navas-Parejo, as well as to Adán Pérez-García for abstract revision. We thank comments and suggestions from an anonymous reviewer and Alberto Pérez-López that improved a previous version of the manuscript, as well as to the Associated Editor Matías Reolid. Authors also want to thank Marina Bonet for her contribution in the finding of the ichnites. E.M. is supported by a PIF grant from the Universitat Autònoma de Barcelona and also by the SYNTHESYS Proyect (DE-TAF-2650 at Museum für Naturkunde; http://www. synthesys.info/).

\section{REFERENCES}

Abel, O. 1935. Vorzeitliche Lebensspuren. Fischer, Jena.

Avanzini, M. \& Cavin, L. 2009. A new Isochirotherium trackway from the Triassic of Vieux Emosson, SW Switzerland: stratigraphic implications. Swiss Journal of Geosciences, 102, 353-361.

Belvedere, M., Jalil, N.-E., Breda, A., Gattolin, G., Bourget, H., Khaldoune, F. \& Dyke, G.J. 2013. Vertebrate footprints from the Kem Kem beds (Morocco): A novel ichnological approach to faunal reconstruction. Palaeogeography, Palaeoclimatology, Palaeoecology, 383-384, 52-58.

Beurlen, K. 1950. Neue Fährtenfunde aus der fränkischen Trias. Neues Jahrbuch für Geologie und Paläontologie, Monatshefte, 1950, 308-320.

Calafat, F., Fornós, J., Marzo, M., Ramos-Guerrero, E. \& Rodríguez-Perea, A. 1987. Icnología de vertebrados de la facies Buntsandstein de Mallorca. Acta Geologica Hispanica, 21-22, 515-520.

Calvet, F. \& Marzo, M. 1994. El Triásico de las Cordilleras Costero Catalanas: Estratigrafía, Sedimentología y Análisis Secuencial. Cuaderno de Excursión. III Coloquio de Estratigrafía y Paleoestratigrafía del Pérmico y Triásico de España. Field Guide. 
Calvet, F. \& Ramón, X. 1987. Estratigrafía, sedimentología y diagénesis del Muschelkalk inferior de los Catalánides. Cuadernos de Geología Ibérica, 11, 141-169.

Calzada, S. 1987. Niveles fosilíferos de la facies Buntsandstein (Trias) en el sector norte de los Catalánides. Cuadernos de Geología Ibérica, 11, 256-271.

Coram, R.A. \& Radley, J.D. 2013. A chirothere footprint from the Otter Sandstone Formation (Middle Triassic, late Anisian) of Devon, UK. Proceedings of the Geologists' Association, 124, 520-524

Demathieu, G. 1985. Trace fossil assemblages in middle Triassic marginal marine deposits, Eastern border of the Massif Central, France. In: Biogenic structures (ed. Curren H.A.). SEPM Special Publications, 35, 53-66.

Demathieu, G. \& Demathieu, P. 2004. Chirotheria and other ichnotaxa of the European Triassic. Ichnos, 11, 79-88.

Demathieu, G. \& Saiz de Omeñaca, J. 1990. Primeros resultados del estudio de un nuevo yacimiento de icnofauna triásica, en Peña Sagra (Cantabria, España). Estudios Geológicos, 46, 147-150.

Demathieu, G., Ramos, A. \& Sopeña, A. 1978. Fauna icnológica del Triásico del extremo noroccidental de la Cordillera Ibérica (Prov. de Guadalajara). Estudios Geológicos, 34, 175-186.

Demathieu, G., Pérez-López, A. \& Pérez-Lorente, F. 1999. Enigmatic ichnites in the Middle Triassic of Southern Spain. Ichnos, 6, 229-237.

Díaz-Martínez, I. \& Pérez-García, A. 2012. Historical and comparative study of the first spanish vertebrate paleoichnological record and bibliographic review of the Spanish Chirotheriid footprints. Ichnos, 19, 141-149.

Diedrich, C. 2008. Millions of reptile tracks - Early to Middle Triassic carbonate tidal flat migration bridges of Central Europe. Palaeogeography, Palaeoclimatology, Palaeoecology, 259, 410-423.

Dinarès-Turell, J., Diez, J.B., Rey, D. \& Arnal, I. 2005. "Buntsandstein" magnetostratigraphy and biostratigraphic reappraisal from eastern Iberia: Early and Middle Triassic stage boundary definitions through correlation to Tethyan sections. Palaeogeography, Palaeoclimatology, Palaeoecology, 229, 158-177.

Durán, H. 1990. El Paleozoico de les Guilleries. Acta Geologica Hispanica, 25, 83-103.

Falkingham, P.L. 2012. Acquisition of high resolution three-dimensional models using free, open-source, photogrammetric software. Palaeontologia Electronica, 15(1), 1-15.

Fortuny, J., Bolet, A., Sellés, A.G., Cartanyà, J. \& Galobart, À. 2011. New insights on the Permian and Triassic vertebrates from the Iberian Peninsula with emphasis on the Pyrenean and Catalonian basins. Journal of Iberian Geology, 37, 65-86.

Fortuny, J., Bolet, A., Oms, O., Bonet, M., Diviu, M., Rodríguez, P. \& Galobart, À. 2012. Permian and Triassic ichnites from the Catalonian and Pyrenean basins (Eastern Iberian Peninsula). 10th Annual Meeting of the EAVP, Abstract book, p. 73-75.
Fuglewicz, R., Ptaszyński, T. \& Rdzanek, K. 1990. Lower Triassic footprints from the Swiqtokrzyskie (Holy Cross) Mountains, Poland. Acta Palaeontologica Polonica, 35, 109-164.

Gand, G., De La Horra, R., Galán-Abellán, B., López-Gómez, J., Fernández-Barrenechea, J., Arche, A. \& Benito, M.I. 2010. New ichnites from the Middle Triassic of the Iberian Ranges (Spain): palaeoenvironmental and palaeogeographical implications. Historical Biology, 22, $1-17$.

García-Bartual, M., Rincón, R. \& Hernando, S. 1996. Propuesta de una nueva técnica de estudio mediante análisis digital de imagen en huellas quiroteroides encontradas en el Triásico de Nuévalos (Provincia de Zaragoza). Cuadernos de Geología Ibérica, 20, 301-312.

Haubold, H. 1966. Therapsiden- und RhynchocephalenFährten aus dem Buntsandstein Südthüringens. Hercynia, $N F, 3,147-183$.

Haubold, H. 1971a. Die Tetrapodenfährten des Buntsandsteins in der Deutschen Demokratischen Republik und in Westdeutschland und ihre Äquivalente in der gesamten Trias. Paläntologische Abhandlungen, Abteilung a Paläozoologie, 395-548.

Haubold, H. 1971b. Ichnia Amphibiorum et Reptiliorum fossilium. Encyclopedia of Paleoherpetology 18. Gustav Fischer Verlag, Stuttgart and Portland-USA.

Hminna, A., Voigt, S., Klein, H., Saber, H., Schneider, J.W. \& Hmich, D. 2013. First occurrence of tetrapod footprints from the continental Triassic of the Sidi Said Maachou area (Western Meseta, Morocco). Journal of African Earth Sciences, 80, 1-7.

Kaup, J.J. 1835. Fährten von Beuteltieren. Das Tierreich, 246-248.

Klein, H. \& Haubold, H. 2003. Differenzierung von ausgewählten Chirotherien der Trias mittels Landmarkanalyse. Hallesches Jahrbuch für Geowissenschaften, B25, 21-36.

Klein, H. \& Lucas, S.G. 2010. Tetrapod footprints - their use in biostratigraphy and biochronology of the Triassic. Geological Society London Special Publications, 334, 419-446.

Klein, H., Voigt, S., Saber, H., Schneider, J.W., Fischer, J., Hminna, A. \& Brosig, A. 2011. First occurrence of a Middle Triassic tetrapod ichnofauna from the Argana Basin (Western High Atlas, Morocco). Palaeogeography, Palaeoclimatology, Palaeoecology, 307, 218-231.

Linol, B., Bercovici, A., Bourquin, S., Diez, J.B., LópezGómez, J., Broutin, J., Durand, M. \& Villanueva-Amadoz, U. 2009. Late Permian to Middle Triassic correlations and palaeogeographical reconstructions in south-western European basins: New sedimentological data from Minorca (Balearic Islands, Spain). Sedimentary Geology, 220, 77-94.

López-Gómez, J., Arche, A. \& Pérez-López, A. 2002. Permian and Triassic. In: The Geology of Spain (eds. Gibbons, W. \& Moreno, T.). Geological Society Publishing House, London, 185-212. 
Maidwell, F.T. 1911. Notes on footprints from the Keuper of Runcorn Hill. Proceedings of the Liverpool Geological Society, 11, 140-152.

Pérez-López, A. 1993. Estudio de las huellas de reptil, del icnogénero Brachychiroterium, encontradas en el Trías Subbético de Cambil. Estudios Geológicos, 49, 77-86.

Petti, F.M., Avanzini, M., Nicosia, U., Girardi, S., Bernardi, M., Ferretti, P., Schirolli, P. \& Sasso, C.D. 2009. Late Triassic (Early-Middle Carnian) chirotherian tracks from the Val Sabbia sandstone (Eastern lombardy, Brescian Prealps, Northern Italy). Rivista Italiana di Paleontologia e Stratigrafia, 115, 277-290.
Solé de Porta, N., Calvet, F. \& Torrentó, L. 1987. Análisis palinológico del Triásico de los Catalánides (NE España). Cuadernos de Geología Ibérica, 11, 237-254.

Valdiserri, D. \& Avanzini, M. 2007. A Tetrapod Ichnoassociation from the Middle Triassic (Anisian, Pelsonian) of Northern Italy. Ichnos, 14, 105-116.

Vía-Boada, L., Villalta, J.F. \& Esteban-Cerdá, M. 1977. Paleontología y Paleoecología de los yacimientos fosilíferos del Muschelkalk superior entre Alcover y Mont-Ral (Montañas de Prades, provincia de Tarragona). Cuadernos de Geología Ibérica, 4, 247-256. 
